\title{
Recovery of Chromium from Slags Leachates by Electrocoagulation and Solid Product Characterization
}

\author{
Lubomir Pikna ${ }^{1, *}$, Maria Hezelova ${ }^{1}$, Agnieszka Morillon ${ }^{2}$, David Algermissen ${ }^{2}$, \\ Ondrej Milkovic ${ }^{3,4}$, Robert Findorak ${ }^{1}$, Martin Cesnek ${ }^{5}$ and Jaroslav Briancin ${ }^{6}$ \\ 1 Faculty of Materials, Metallurgy and Recycling, Technical University of Kosice, \\ Letna 9, 04200 Kosice, Slovakia; maria.hezelova@tuke.sk (M.H.); robert.findorak@tuke.sk (R.F.) \\ 2 FEhS-Institut fürBaustoff-Forschung e. V., 47229 Duisburg, Germany; a.morillon@fehs.de (A.M.); \\ d.algermissen@fehs.de (D.A.) \\ 3 Institute of Materials Research, Slovak Academy of Sciences, Watsonova 47, 04001 Kosice, Slovakia; \\ omilkovic@saske.sk \\ 4 Institute of Experimental Physics, Slovak Academy of Sciences, Watsonova 45, 04001 Kosice, Slovakia \\ 5 Faculty of Nuclear Sciences and Physical Engineering, Czech Technical University in Prague, \\ V Holesovickach 2, 18000 Prague, Czech Republic; martin.cesnek@fjfi.cvut.cz \\ 6 Institute of Geotechnics, Slovak Academy of Sciences, Watsonova 45, 04001 Kosice, Slovakia; \\ briancin@saske.sk \\ * Correspondence: lubomir.pikna@tuke.sk; Tel.: +421-55-602-2307
}

Received: 16 October 2020; Accepted: 26 November 2020; Published: 27 November 2020

\begin{abstract}
Slags produced in the steelmaking industry could be a source of chromium. Slags contain, depending on different types of slags, between 2 to $5 \mathrm{wt}$.\% of Cr. Roasting of slag with $\mathrm{NaOH}$, followed by subsequent leaching can produce leachates which can be efficiently processed using electrocoagulation (EC). This paper provides results from the EC process optimization for $\mathrm{Cr}(\mathrm{VI})$ solutions with initial concentration $1000 \mathrm{mg} / \mathrm{L}$ of $\mathrm{Cr}(\mathrm{VI})$. Influence of $\mathrm{pH}$, current intensity and $\mathrm{NaCl}$ concentration on the efficiency of chromium recovery, energy consumption as well as solid product composition is discussed in detail. Optimum of $\mathrm{pH}=6$ was chosen for $\mathrm{EC}$ processing of $\mathrm{Cr}$ leachates as well as current intensities of $0.1-0.5 \mathrm{~A}$ because of the higher $\mathrm{Cr} / \mathrm{Fe}$ ratio in solid product compared to higher current intensities. Results of EC processing of four real leachates of electric arc furnace carbon steel slag (EAFC), electric arc furnace stainless steel slag (EAFS), low carbon ferrochrome slag ( $\mathrm{LC} \mathrm{FeCr}$ ) and high carbon ferrochrome slag $(\mathrm{HC} \mathrm{FeCr}$ ) were evaluated. Comparison of the results of four real leachate samples is presented. Obtained final solid product was identified as $\left(\mathrm{Fe}_{0.6} \mathrm{Cr}_{0.4}\right)_{2} \mathrm{O}_{3}$ and with up to $20 \%$ of $\mathrm{Cr}$ could be used as source of chromium in the ferrochrome production.
\end{abstract}

Keywords: chromium; electrocoagulation; metal recovery; secondary raw materials; leaching; slag

\section{Introduction}

Chromium is an important element in the steelmaking industry, whether it is a production of steel, stainless steel or ferrochrome. During these processes, several by-products, such as slags, dusts, mill-scales and sludges are produced. It is $200 \mathrm{~kg}$ (in the scrap-based steelmaking) and $400 \mathrm{~kg}$ (in the iron ore-based steelmaking) per one ton of produced steel. According to the type of steel or ferrochrome, there are different levels of content of chromium present. The industry is working proactively to produce slag that can be used in different applications [1] by making sure the chromium found in the slag is in stable spinel compounds which have very low solubility [2]. Depending on the type of slag and its quality, the leachability characteristics may lead to it being classified as waste, based on local regulations, which restricts its use [3]. Chromium can exist in unstable phases, such as dicalcium silicate $\left(\mathrm{Ca}_{2} \mathrm{SiO}_{4}\right)$, merwinite $\left(\mathrm{Ca}_{3} \mathrm{MgSi}_{2} \mathrm{O}_{8}\right)$, melilite $\left(\mathrm{Ca}_{2} \mathrm{Mg}_{2} \mathrm{SiO}_{7}\right)$, gehlenite $\left(\mathrm{Ca}_{2} \mathrm{Al}_{2} \mathrm{SiO}_{7}\right)$ and periclase 
(MgO). $\mathrm{Cr}$ (II) and $\mathrm{Cr}$ (III) can be released after phase decomposition, followed by oxidation to $\mathrm{Cr}(\mathrm{VI})$ [4]. While $\mathrm{Cr}(\mathrm{III})$ is an essential trace element, the $\mathrm{Cr}(\mathrm{VI})$ compounds are very toxic (100-1000 times more toxic than $\mathrm{Cr}(\mathrm{III}))$ and highly leachable.

In terms of metal recovery, slag is a source of $\mathrm{Cr}, \mathrm{V}, \mathrm{Mn}$ or Mo, obtainable by applying appropriate extensive treatment to the slag to liberate part of these elements in oxide form which can be recovered by electrocoagulation (EC).

Electrocoagulation is a simple electrochemical method exploiting in situ production of coagulant agent (metallic cations) by electrodissolution of soluble anodes, usually made of iron or aluminum. Production of $\mathrm{H}_{2}$ typically occurs at the cathode. Electrocoagulation has been successfully used to treat different industrial wastewaters such as: textile wastewater [5], chemical mechanical polishing wastewater [6], sanitary landfill leachates [7], waste metal cutting fluids [8], paper mill wastewater [9], pesticide [10] and phosphate and nitrogen removal [11]. Research in the last few decades have proved that $\mathrm{EC}$ is an effective technology for treatment of industrial wastewaters for the recovery of different metal ions, such as $\mathrm{Cr}(\mathrm{III}), \mathrm{Cr}(\mathrm{VI}), \mathrm{Ni}(\mathrm{II}), \mathrm{Cu}(\mathrm{II}), \mathrm{As}(\mathrm{V}), \mathrm{Al}(\mathrm{III}), \mathrm{Zn}(\mathrm{II}), \mathrm{Ag}(\mathrm{I})$ [12-19] with efficiencies of $90-100 \%$, depending on the specific conditions of the experiment. Many papers have focused on the removal of $\mathrm{Cr}(\mathrm{VI})$ and $\mathrm{Cr}(\mathrm{III})$ from different types of models or real wastewaters by applying electrocoagulation or another electrochemical methods [16,20-23]. In order to optimize the EC removal efficiency of $\mathrm{Cr}(\mathrm{VI})$, different parameters such as initial $\mathrm{Cr}(\mathrm{VI})$ concentration, temperature, $\mathrm{pH}$, current density as well as the influence of different supporting electrolytes $\left(\mathrm{NaCl}, \mathrm{Na}_{2} \mathrm{SO}_{4}\right.$ and $\mathrm{NaNO}_{3}$ ) have been systematically investigated [12,13,24]. According to E-pH diagram, the $\mathrm{pH}$ plays a significantly important role for $\mathrm{Cr}(\mathrm{VI})$ treatment due to the highly $\mathrm{pH}$-dependent speciation and solubility of reaction products [25]. Jin et al. [25] described the $\mathrm{Cr}(\mathrm{VI})$ removal efficiency of nearly $99 \%$ in the range of $\mathrm{pH}$ between 5 and 8 . In contrast, $\mathrm{pH}$ higher than 8 significantly decreased the removal efficiency of $\mathrm{Cr}(\mathrm{VI})$. This resulted from the reduction of $\mathrm{Cr}(\mathrm{VI})$ to $\mathrm{Cr}(\mathrm{III})$ as the solubility of formed hydroxides increased in alkaline solution. Approximately $50 \% \mathrm{Cr}$ (III) remained dissolved in the solution at $\mathrm{pH} 4.5$ [25]. Therefore, $\mathrm{pH}$ lower than 5 is not recommended. Results of Lakshmipathiraj et al. [24], showed that $\mathrm{Cr}(\mathrm{VI})$ concentration was reduced more efficiently in the presence of $\mathrm{NaCl}$, while there was smaller removal in the presence of $\mathrm{Na}_{2} \mathrm{SO}_{4}$ or $\mathrm{NaNO}_{3}$. Passivation of the electrodes and subsequent disabling of the anode dissolution plays a key role in the EC process. However, this passivation could be limited, and the dissolution of iron was promoted by the presence of chloride ion [26].

Vasudevan et al. [27], investigated the effect of anode materials (Al-Zn-In alloy material and Fe) towards the $\mathrm{Cr}(\mathrm{VI})$ electrocoagulation, and found the removal efficiency in the case of $\mathrm{Al}$ anode was lower than with mild steel. Barrera-Diaz et al. [28] compared the effect of different cathodic materials, such as Al, stainless steel and copper. The conclusion was that the copper is the best one due to its higher electrocatalytic activity towards the direct reduction of $\mathrm{Cr}(\mathrm{VI})$. Many combinations of anode and cathode materials were tested, including aluminum, steel, stainless steel, copper and carbon. The combination of steel-steel as cathode and anode forms an inexpensive and highly effective pair of materials.

Arroyo et al. [12] described the mechanisms and reactions involved in the electrocoagulation of $\mathrm{Cr}(\mathrm{VI})$ as follows:

1. Formation of coagulants by electrolytic oxidation of the anode.

2. Destabilization of the contaminants, particulate suspension and breaking of emulsions.

3. Aggregation of the destabilized phases to form flocks.

If iron is employed as an anode material, its electrochemical oxidation generates $\mathrm{Fe}^{2+}$ ions which can directly reduce $\mathrm{Cr}(\mathrm{VI})$ to $\mathrm{Cr}(\mathrm{III})$. Depending on the solution $\mathrm{pH}$, the generated $\mathrm{Fe}^{3+}$ ions will immediately undergo further spontaneous reactions to produce various monomeric and/or polymeric metal hydroxides complexes which remain in the aqueous stream and which can remove the pollutants from wastewater either by complexation or by electrostatic attraction, followed by coagulation. 
The increase of the solution $\mathrm{pH}$ due to hydroxyl ions which are produced at the cathode causes the coprecipitation of $\mathrm{Cr}(\mathrm{III})$ and $\mathrm{Fe}(\mathrm{III})$ as $\mathrm{Cr}_{x} \mathrm{Fe}_{1-x}(\mathrm{OH})_{3}$ between $\mathrm{pH} 2$ and 6, acting synergistically to remove the pollutants from water. At a higher $\mathrm{pH}, \mathrm{Cr}^{3+}$ ions can precipitate as $\mathrm{Cr}(\mathrm{OH})_{3}$. If the anode potential is sufficiently high, secondary reactions may occur at the anode surface, such as the oxidation of $\mathrm{H}_{2} \mathrm{O}$ and $\mathrm{Cl}^{-}$ion [12].

The present paper provides results of the EC process optimization for $\mathrm{Cr}(\mathrm{VI})$ solutions with initial concentration of $\mathrm{Cr}(\mathrm{VI})$ of $1000 \mathrm{mg} / \mathrm{L}$. The efficiency of chromium recovery, energy consumption as well as solid product composition is correlated with $\mathrm{pH}$, current intensity and $\mathrm{NaCl}$ concentration. Results of EC processing of real leachates (chromium concentration from 687 to $2191 \mathrm{mg} / \mathrm{L}$ ) of different slags are also presented.

\section{Materials and Methods}

\subsection{Leachates Preparation}

Electrocoagulation experiments with model solutions prepared from potassium dichromate were realized for concentration of $1000 \mathrm{mg} / \mathrm{L}$ of $\mathrm{Cr}$ as well as the real leachates of 4 different slag types: electric arc furnace carbon steel slag (EAFC) (2.33\% of Cr), electric arc furnace stainless steel slag (EAFS) $(0.82 \%$ of Cr), low carbon ferrochrome slag (LC FeCr) $(1.10 \%$ of $\mathrm{Cr}$ ) and high carbon ferrochrome slag ( $\mathrm{HC} \mathrm{FeCr}$ ) (11.21\% of $\mathrm{Cr}$ ). EAFC, EAFS, HC FeCr slags had grain size $<1 \mathrm{~mm}$ while LC FeCr slag had grain size of 2-4 mm (In further texts, these marks will be used for leachates of particular slags and solid products prepared by EC process). The grain size was chosen based on previous tests, which showed the maximum efficiency that can be reached. A total of $100 \mathrm{~g}$ of each slag was roasted with an addition of $20 \mathrm{~g}$ of $\mathrm{NaOH}$ at $1000^{\circ} \mathrm{C}$ for $4 \mathrm{~h}$. The energy for running the laboratory furnace was $70 \mathrm{kWh}$ during $4 \mathrm{~h}$, however 25 crucibles with $150 \mathrm{~g}$ of sample could fit in the furnace at the same time. In total, 2 consecutive leaching tests were conducted on each roasted slag sample. A total of $100 \mathrm{~g}$ of each slag was mixed with $500 \mathrm{~mL}$ of water, weighted and mixed overhead for $1 \mathrm{~h}$, then the slag was allowed to settle down and water was separated from it. The sample was weighted, and additional water was added to reach the initial weight. The same procedure was repeated second time. The two obtained solutions were mixed and used in EC process. Chemical and mineralogical composition of slags was previously published by Horckmans et al. [29]. Table 1 lists parameters of tested real leachates including $\mathrm{pH}$ adjustment with $\mathrm{NaCl}$ amount crystalized and solution conductivity.

Table 1. Real leachates parameters.

\begin{tabular}{|c|c|c|c|c|c|}
\hline Real Leach. Mark & c $(\mathrm{Cr})(\mathrm{mg} / \mathrm{L})$ & Original pH & $\begin{array}{l}\mathrm{V}(\mathrm{HCl} 1: 1) \text { Added to } \\
100 \mathrm{~mL} \text { of Leachate for } \\
\text { pH Adjusting to } 6(\mathrm{~mL})\end{array}$ & $\begin{array}{l}\mathrm{NaCl} \text { Produced } \\
\text { from } 100 \mathrm{~mL} \text { of } \\
\text { Leachate }(\mathrm{g})\end{array}$ & $\mathrm{G}^{*}(\mathrm{mS})$ \\
\hline EAFS & 2191 & 12.5 & 2.36 & 0.414 & 17.37 \\
\hline EAFC & 942 & 12.6 & 1.69 & 0.416 & 12.67 \\
\hline $\mathrm{LC} \mathrm{FeCr}$ & 687 & 12.6 & 1.33 & 0.333 & 9.4 \\
\hline $\mathrm{HC} \mathrm{FeCr}$ & 2013 & 10.5 & 0.67 & - & 8.8 \\
\hline
\end{tabular}

${ }^{*}$ Conductivity was measured after $\mathrm{pH}$ was adjusted to 6 and after filtration of crystallized $\mathrm{NaCl}$.

\subsection{EC Process Conditions}

A Laboratory Power Supply EA-PS 3032-10B (ELEKTRO-AUTOMATIK), max output 10 A and $32 \mathrm{~V}$-DC source, shaft stirrer WISESTIR HT50DX (witeg Labortechnik GmbH, Wertheim, Germany) with rpm regulation and $\mathrm{pH}$ meter ORION 3 STAR (Thermo Fisher Scientific Inc., Waltham, MA, USA) were employed in experiments.

In total, 2 steel plates, ST37-2, with dimensions of $150 \times 40 \times 2 \mathrm{~mm}^{3}$ and active surface with dimensions $50 \times 40 \times 2 \mathrm{~mm}^{3}$ were used as electrodes. 
Influence of $\mathrm{NaCl}$ concentration on $\mathrm{EC}$ of chromium was verified for 6 concentrations: 1000, 2000, $3000,10,000,30,000$ and $50,000 \mathrm{mg} / \mathrm{L}$ of $\mathrm{NaCl}$.

Influence of $\mathrm{pH}$ on EC of chromium was verified for 3 values: $4.5,6$ and 8 . For adjustment of $\mathrm{pH}$ at the beginning of experiment and regulation for the entire duration of the experiment, solution of 1:1 hydrochloric acid was used.

Current intensities of $0.1,0.5,1$ and 2 A were tested in EC process.

Volume of solutions and rotations of shaft stirrer were constant for each experiment, $350 \mathrm{~mL}$ and $250 \mathrm{rpm}$, respectively.

EC experiments with model solution lasted for $120 \mathrm{~min}$ and samples of $6 \mathrm{~mL}$ were taken to determine the $\mathrm{Cr}$ concentration at the following intervals: 0, 5, 10, 15, 20, 30, 40, 50, 60, 80, 100, $120 \mathrm{~min}$. After optimization, for real leachate samples, different sampling intervals were chosen because a longer time was needed to recover all of the $\mathrm{Cr}$ from solution (up to $8 \mathrm{~h}$ depending on the $\mathrm{Cr}$ concentration in leachate). Samples were filtered and the filtrates were analyzed for $\mathrm{Cr}$ concentration by atomic absorption spectrometry (VARIAN 20+) (in all tables, graphs and calculations, concentration of $0 \mathrm{mg} / \mathrm{L}$ means it was under LOQ of AAS). AAS was also used for $\mathrm{Cr}$ and Fe analysis in the solid product (after decomposition). Experimental setup of EC experiment is shown in Figure 1.

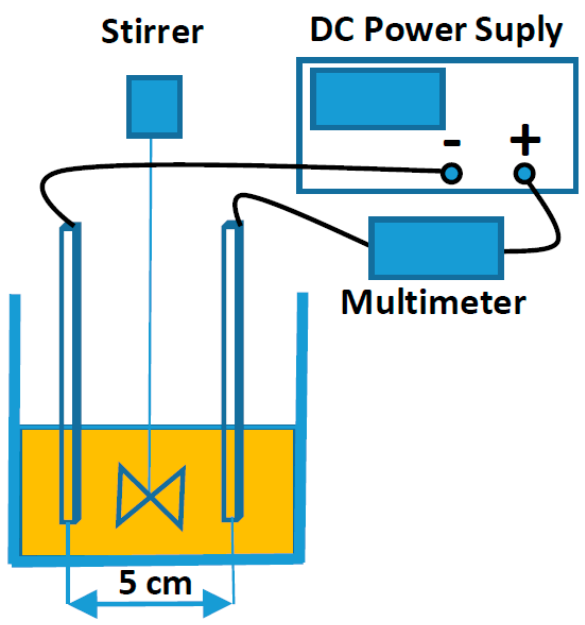

Figure 1. Electrocoagulation (EC) experimental setup of slag leachates processing.

\subsection{Methods Used for Solid Product Characterization}

Solid product characterization was also realized by TG analysis, XRF, EDX, XRD analysis and Mössbauer spectroscopy. Derivatograph C, MOM, was used for TGA measurements of direct EC process product weight change under heating conditions. Thermal gradient of sample heating was $10^{\circ} \mathrm{C} / \mathrm{min}$. XRF analysis was realized before and after thermal treatment of samples $\left(850{ }^{\circ} \mathrm{C}\right.$ for $\left.2 \mathrm{~h}\right)$ by portable XRF analyzer THERMO NITON XL3 GOLD (Thermo Fisher Scientific Inc., Waltham, MA, USA), in the ore mode, based on the oxidic character of samples. XRD measurements were realized by RIGAK ULTIMA IV type II (Rigaku Corporation, Tokyo, Japan) with a Cu lamp. Diffraction pattern was refined by Rietveld method using MAUD software (University of Trento, Trento, Italy) [30] with focusing to determine the lattice parameter of the powder. Scanning electron microscope (SEM), TESCAN MIRA 3 FE (TESCAN ORSAY HOLDING, a.s., Brno, Czech Republic), with microanalytical EDX equipment, OXFORD INSTRUMENTS (Oxford Instruments plc, Abingdon, UK), was used for characterization. Mössbauer spectra were recorded in transmission geometry using constant acceleration spectrometer with a $57 \mathrm{Co} / \mathrm{Rh}$ source. Spectra were recorded at room temperature (RT) and at $4.2 \mathrm{~K}$ using a liquid helium bath cryostat. All the resulting isomer shifts were quoted relative to the spectrum of $12.5 \mu \mathrm{m}$ thin bcc-Fe foil recorded at RT. The spectral parameters comprising of the isomer shift (IS), quadrupole splitting/quadrupole shift (QS), hyperfine magnetic field (B), line width $(\Gamma)$, and area $(A)$ of spectral components were refined by the CONFIT curve-fitting program [31]. 


\section{Results and Discussion}

\subsection{Influence of $p H$}

To determine the influence of $\mathrm{pH}$ on removal of chromium from solution, experiments with model solutions were realized and $\mathrm{pH}$ was kept constant, at a value of $4.5,6$ or 8 , for the entire duration of the experiment. The results showed that for $\mathrm{pH}$ values higher or lower than 6, longer EC duration was necessary to achieve $100 \%$ efficiency of chromium removal. At pH 4.5 and 8 , experiments ended (the concentration of $\mathrm{Cr}$ in solution reached $0 \mathrm{mg} / \mathrm{L}$ ) approximately around 20 and $40 \mathrm{~min}$ later, respectively, than in the case of $\mathrm{pH} 6$ (Figure 2). Experiments without $\mathrm{pH}$ regulation were also completed, where the $\mathrm{pH}$ was set at the beginning to be either 6 or 8 but not regulated by addition of $\mathrm{HCl}$ during the experiment. These experiments lasted about 20 min longer than when the $\mathrm{pH}$ was maintained at 6 or 8 through the whole experiment (higher energy consumption). pH value of 6 was chosen as optimal for this procedure, due to shorter duration to complete the precipitation of $\mathrm{Cr}$ which results in lower energy consumption.

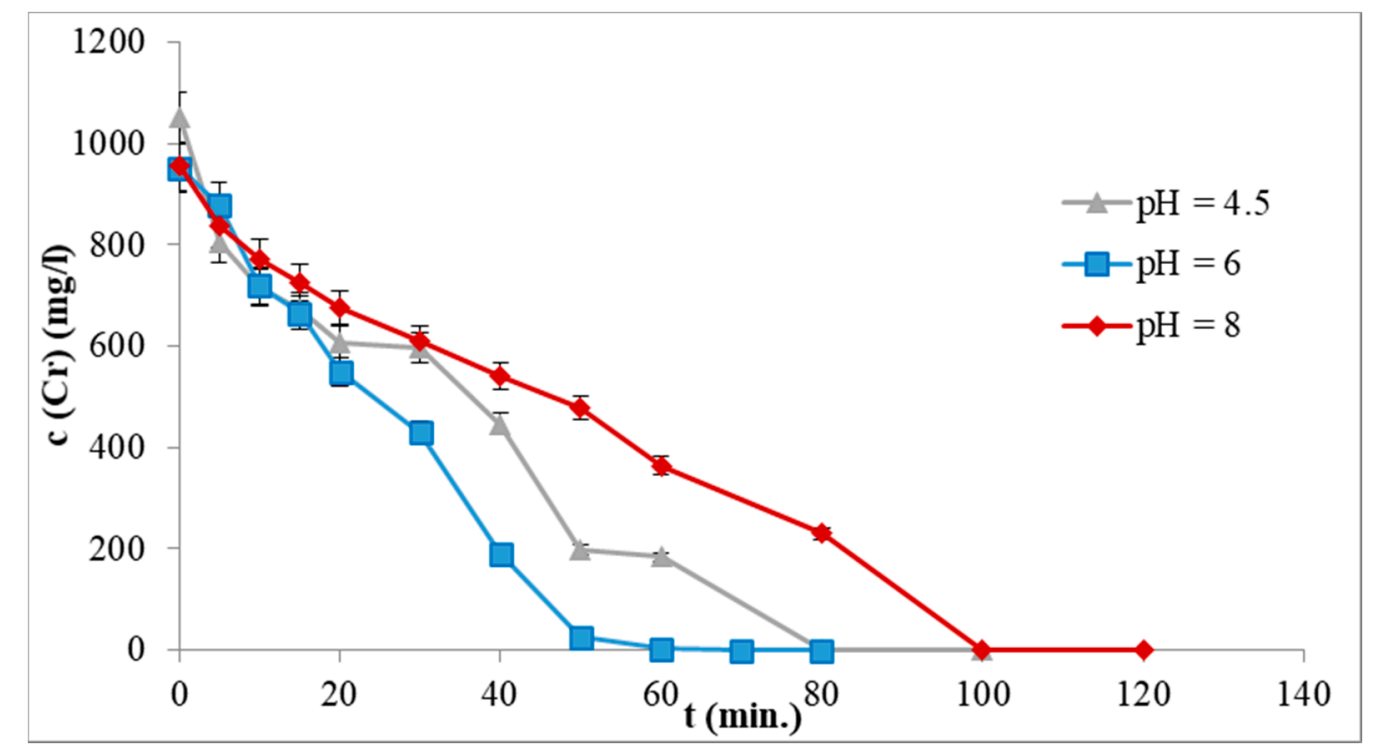

Figure 2. Decrease of $\mathrm{Cr}$ concentration in model solutions for different $\mathrm{pH}$ values, $\mathrm{c}(\mathrm{NaCl})=3000 \mathrm{mg} / \mathrm{L}$, $\mathrm{I}=1 \mathrm{~A}$.

\subsection{Influence of Current Intensity}

The concentration of chromium in solution is an important parameter for the EC process. It dictates the current intensity that is needed for its fast removal. Current intensity influence was studied for values of $0.1,0.5,1$ and 2 A. Application of higher current intensities ( 1 or $2 \mathrm{~A}$ ) led to shorter time of EC process necessary for the total Cr removal from solution. The time reduction was 80 and $50 \mathrm{~min}$, respectively, instead of $120 \mathrm{~min}$, but at the same time it led to the solution overheating up to $60{ }^{\circ} \mathrm{C}$.

For lower current intensities 0.1 and 0.5 A only $67 \%$ and $97 \%$ chromium removal efficiencies were achieved in $120 \mathrm{~min}$ and working temperatures were in the range of $25-30{ }^{\circ} \mathrm{C}$ (Figure 3 ). A $100 \%$ efficiency of chromium removal was achieved for $0.5 \mathrm{~A}$ after $140 \mathrm{~min}$ and for $0.1 \mathrm{~A}$ after $430 \mathrm{~min}$ of the EC process. 


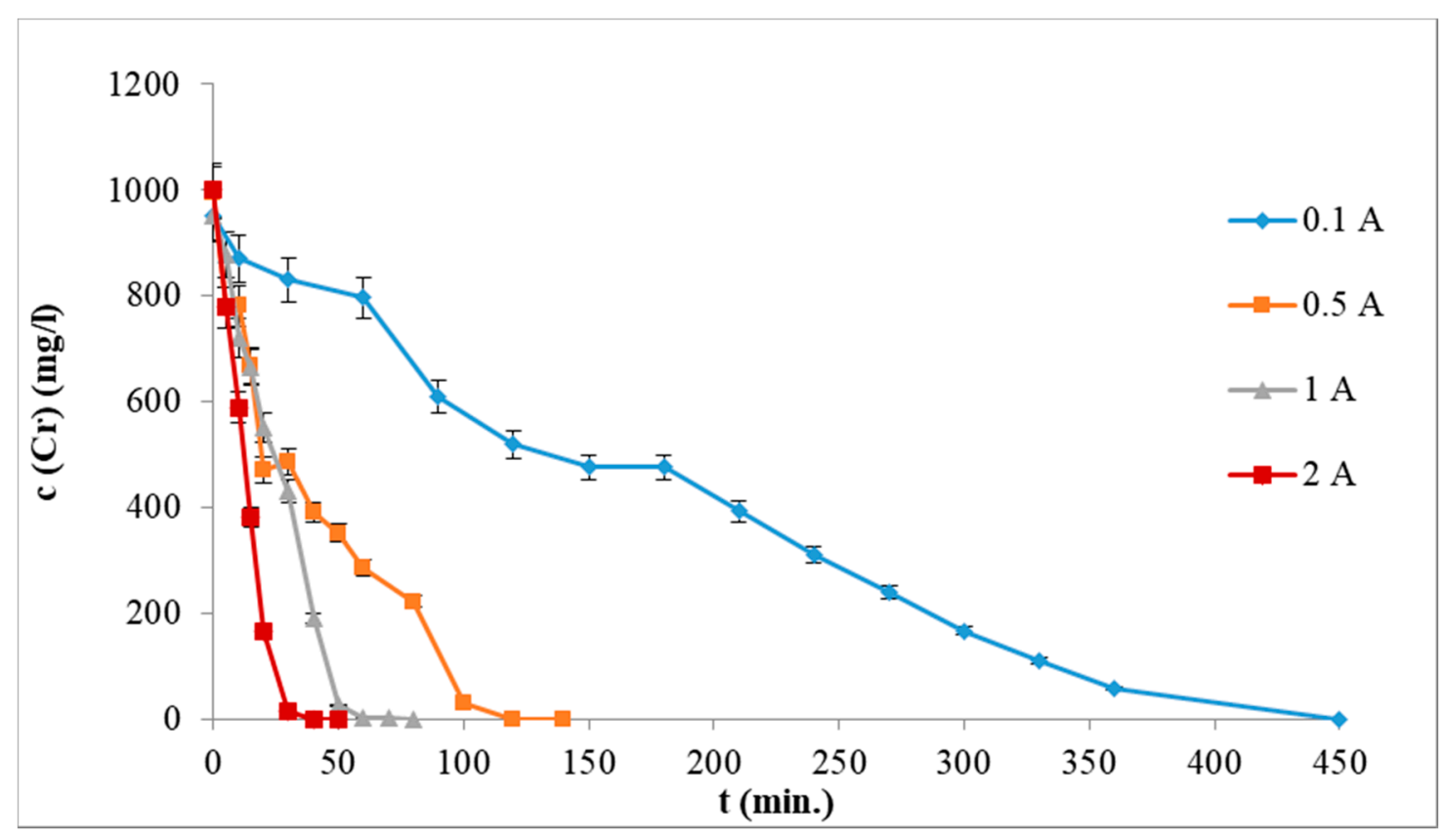

Figure 3. Decrease of Cr concentration for different current intensities, model solution, $\mathrm{c}(\mathrm{NaCl})=3000 \mathrm{mg} / \mathrm{L}$, $\mathrm{pH}=6$.

\subsection{Influence of $\mathrm{NaCl}$}

Dissolved sodium chloride plays many roles in the EC process [24] including:

- prevention of electrode passivation,

- anode corrosion agent, liberating Fe(II) ions into the solution,

- ameliorating the conductivity of the solution.

The presence of sodium chloride is effective for successful $\mathrm{Cr}$ recovery, but very high $\mathrm{NaCl}$ concentrations could be counterproductive, as it would lead to a greater proportion of Fe in the solid product. The concentration of 1000, 2000 or $3000 \mathrm{mg} / \mathrm{L}$ of $\mathrm{NaCl}$ (conductivities of solutions were $\mathrm{G}=4,6$ or $7.2 \mathrm{mS}$ ) were used in the experiments. In experiment without the presence of $\mathrm{NaCl}$, no solid product was created for $2 \mathrm{~h}$, and after the addition of $\mathrm{NaCl}(1000 \mathrm{mg} / \mathrm{L})$, the chromium concentration rapidly declined (decrease of $37.5 \%$ ) and solid product was formed within $40 \mathrm{~min}$. Additionally, experiments with $10,000,30,000$ and $50,000 \mathrm{mg} / \mathrm{L}$ of $\mathrm{NaCl}$ (conductivity $\mathrm{G}=18.2,42$ or $60 \mathrm{mS}$ ) were realized to investigate the effect of more typical $\mathrm{NaCl}$ concentration found in real leachates. As the results showed, concentration of $\mathrm{NaCl}$ (when the same conditions of $\mathrm{pH}$ and current intensity were applied) had no influence on the experiment duration but affected the proportion of Fe in the solid product, as well as the energy consumption during experiments. A higher $\mathrm{NaCl}$ concentration equals lower energy consumption (Figure 4). 


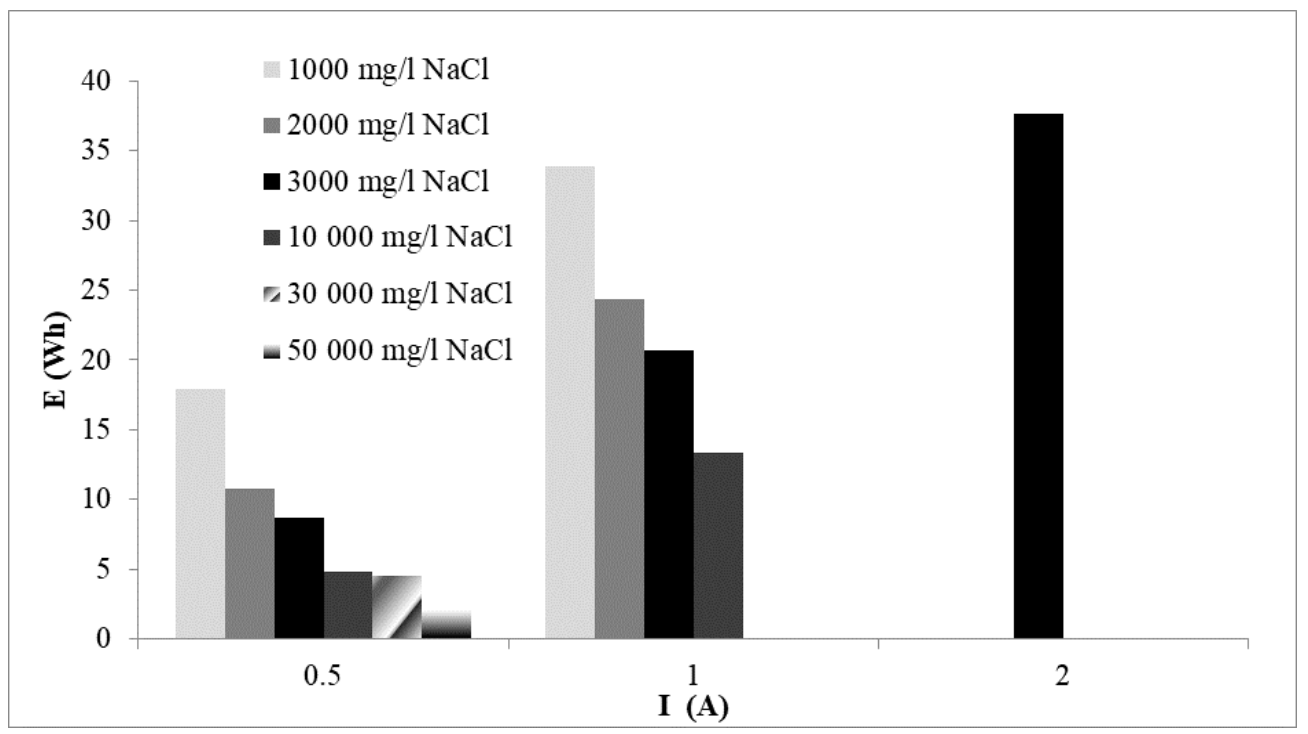

Figure 4. Dependence of EC energy consumption on current intensity and $\mathrm{NaCl}$ concentration. Volume $=350 \mathrm{~mL}$, model solution, $\mathrm{pH}=6$.

\subsection{Energy Consumption of EC Process}

Energy consumption was calculated from the initial time until $\mathrm{Cr}$ concentration was zero in the solution for each experiment. For higher $\mathrm{NaCl}$ concentrations with higher solution conductivity, lower current intensities, resulting in lower energy consumption, could be applied (Figure 4). These results are in good agreement with the results of Khan et al. [17]. The $\mathrm{pH}$ of 6 appears to be the optimal working $\mathrm{pH}$ for these experiments. Other $\mathrm{pH}$ values (4.5 and 8 ) require higher energy consumption. Results in Figure 5 suggest the necessity of $\mathrm{pH}$ regulation for the entire duration of the experiment.

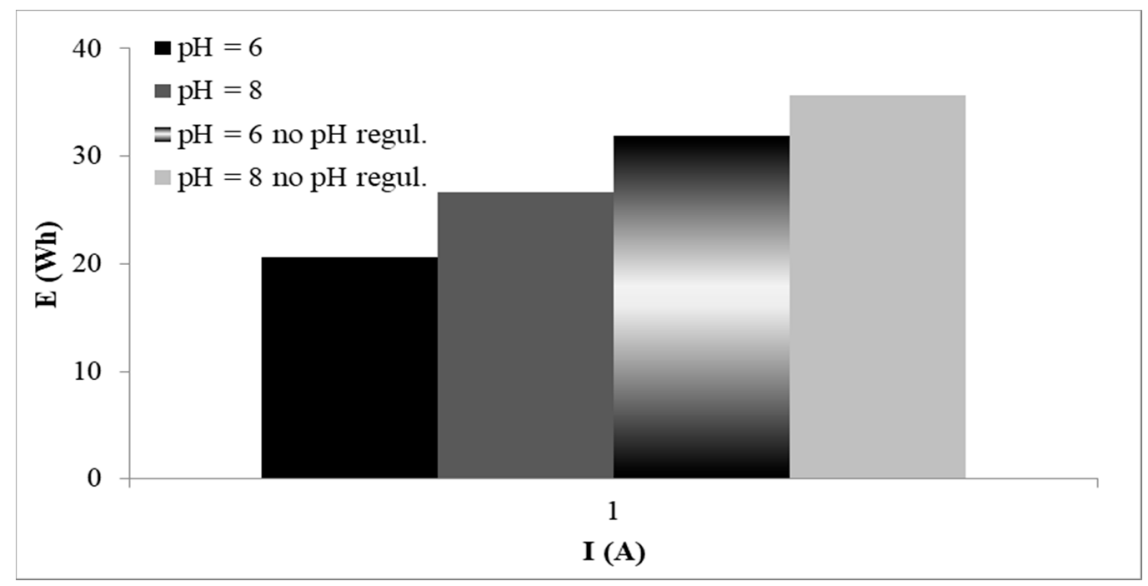

Figure 5. EC energy consumption with and without $\mathrm{pH}$ regulation. Volume $=350 \mathrm{~mL}$, model solution, $c(\mathrm{NaCl})=3000 \mathrm{mg} / \mathrm{L}$.

The following optimized parameters for the EC process have been derived from the experimental work with model solutions:

- $\quad$ an optimized $\mathrm{pH}$ of 6 ,

- optimized energy consumption and presence of iron in the product requires a moderate concentration of $\mathrm{NaCl}$ of around $3000 \mathrm{mg} / \mathrm{L}$, 
- to maximize the $\mathrm{Cr} / \mathrm{Fe}$ ratio, low current intensities (0.1-0.5 A) are needed (energy consumption is always lowered by decreasing the current intensity),

- to remove all of $\mathrm{Cr}$ from solution in shorter time, high current intensities (2 A) must be employed.

\subsection{Real Leachates}

The influence of $\mathrm{NaCl}$ was studied with real leachate of EAFC sample. The sample had sufficient conductivity, but $\mathrm{pH}$ was over 12 . When an experiment with this original solution was realized, no solid product was obtained. Therefore, it was necessary to adjust the $\mathrm{pH}$ to this optimized value of 6 before starting the EC process. Immediately after the $\mathrm{pH}$ was adjusted with addition of $\mathrm{HCl}(1: 1)$, sodium chloride crystallization from solution was observed (identified by XRD analysis). The white crystals that appeared in the solution were filtered out. The conductivity was still sufficient and higher than for the model solutions with addition of $\mathrm{NaCl}$. No addition of $\mathrm{NaCl}$ to real leachate was therefore needed. The efficiency of chromium recovery was $100 \%$ and the duration of the experiment was the same as with $\mathrm{NaCl}$ addition in model samples. For further experiments, the $\mathrm{pH}$ was adjusted with $\mathrm{HCl}(1: 1)$, without $\mathrm{NaCl}$ addition and the current intensity was $0.1 \mathrm{~A}$. Parameters of tested real leachates are in Table 1.

Chromium decrease from solution was time dependent (Figure 6). Duration of experiment was proportional to the initial $\mathrm{Cr}$ concentration (higher concentration, longer time), but not in all cases. $\mathrm{HC} \mathrm{FeCr}$ had lower initial concentration of $\mathrm{Cr}$, but complete removal of $\mathrm{Cr}$ took about 120 min longer than for EAFS. This was due to higher conductivity in $\mathrm{HC} \mathrm{FeCr}$ sample, resulting in more frequent interactions of solution ions with Fe electrode, which lead to the production of Fe ions and subsequent coagulation of $\mathrm{Cr}$ from solution.

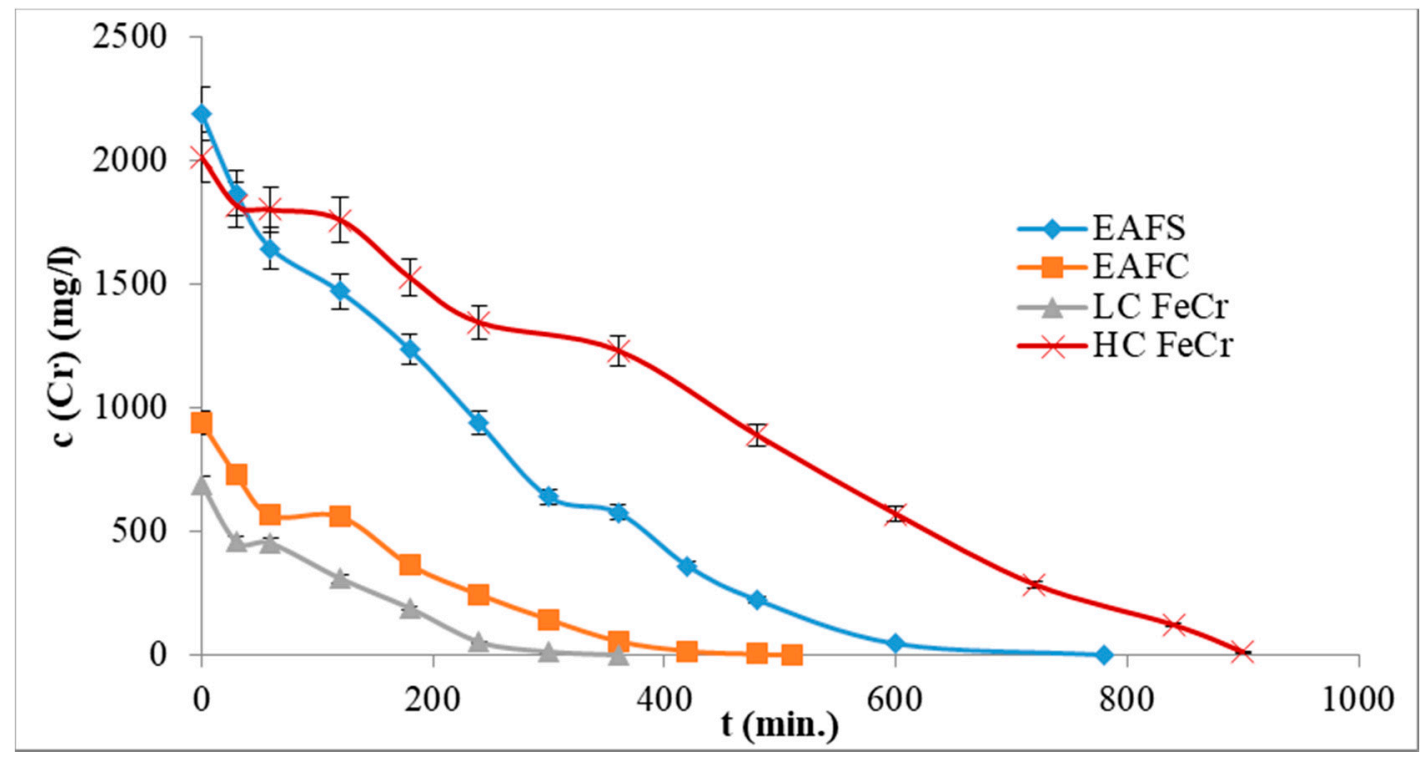

Figure 6. Time dependence of EC process on $\mathrm{Cr}$ concentration for real leachates of slags EAFS, EAFC, LC FeCr, HC FeCr, I = 0.1 A, pH = 6.

\subsection{EC solid Product Characterisation}

After EC process, solid product was filtered and dried at $90{ }^{\circ} \mathrm{C}$ to constant weight. AAS analysis of $\mathrm{Fe}$ and $\mathrm{Cr}$ was realized and results were used for $\mathrm{Cr} / \mathrm{Fe}$ ratio calculation. Experimental conditions including $\mathrm{pH}, \mathrm{NaCl}$ and current intensity exert an influence on the ratio of $\mathrm{Cr} / \mathrm{Fe}$ in the solid product (Table 2). Low current intensities resulted in higher $\mathrm{Cr} / \mathrm{Fe}$ ratio in the solid product as could be seen from the model solution with $\mathrm{c}(\mathrm{Cr})=1000 \mathrm{mg} / \mathrm{L}$, the $\mathrm{Cr} / \mathrm{Fe}$ ratio increased from 0.1818 at $2 \mathrm{~A}$ to 0.3614 at $0.1 \mathrm{~A}$. Concentration of $\mathrm{NaCl}$ in solution influenced the $\mathrm{Cr} / \mathrm{Fe}$ ratio as well. Increasing of $\mathrm{NaCl}$ 
concentration from 3000 to $50,000 \mathrm{mg} / \mathrm{L}$ caused $\mathrm{Cr} / \mathrm{Fe}$ ratio to decrease in value of 0.2922 to 0.1351 . Energy consumption necessary for processing of $1 \mathrm{~m}^{3}$ of different solutions was also calculated and results are summarized in Table 2. Higher current intensities led to a faster decrease of $\mathrm{Cr}$ concentration in the solution, but at the same time a higher Fe amounts were present in the solid products.

Table 2. Amount of $\mathrm{Cr}$ and $\mathrm{Fe}$ in the EC solid product and energy consumption for different current intensities and $\mathrm{NaCl}$ concentrations at $\mathrm{pH}=6$.

\begin{tabular}{ccccccccc}
\hline Sample & $\mathbf{c}(\mathbf{C r})(\mathbf{m g} / \mathbf{L})$ & $\mathbf{I}(\mathrm{A})$ & $\mathbf{U}(\mathbf{V})$ & $\mathbf{c}(\mathbf{N a C l})(\mathbf{m g} / \mathbf{L})$ & $\mathbf{C r}(\mathbf{g} / \mathbf{k g}) *$ & $\mathbf{F e}(\mathrm{g} / \mathbf{k g})$ & Ratio Cr:Fe & $\begin{array}{c}\text { Energy Consumption } \\
\left(\mathbf{k W h} / \mathbf{m}^{3}\right)\end{array}$ \\
\hline model 1 & 1000 & 0.1 & 2.6 & 3000 & 138.9 & 384.3 & 0.3614 & 5.57 \\
\hline model 2 & 1000 & 0.5 & 8.5 & 3000 & 107.5 & 367.9 & 0.2922 & 24.65 \\
\hline model 3 & 1000 & 1 & 16 & 3000 & 95.8 & 388.3 & 0.2467 & 59.00 \\
\hline model 4 & 1000 & 2 & 25 & 3000 & 79.6 & 437.8 & 0.1818 & 107.52 \\
\hline model 5 & 1000 & 0.5 & 4 & 10,000 & 79.5 & 364.3 & 0.2182 & 13.83 \\
\hline model 6 & 1000 & 0.5 & 2.5 & 30,000 & 84.3 & 384.5 & 0.2192 & 12.98 \\
\hline model 7 & 1000 & 0.5 & 2 & 50,000 & 98.3 & 727.8 & 0.1351 & 6.76 \\
\hline EAFS & 2191 & 0.1 & 1.8 & not add. & 156.6 & 357.9 & 0.4376 & 6.64 \\
\hline EAFC & 942 & 0.1 & 1.8 & not add. & 140 & 340.6 & 0.4110 & 4.21 \\
\hline LC FeCr & 687 & 0.1 & 2.2 & not add. & 141.1 & 346.1 & 0.4077 & 3.74 \\
\hline HC FeCr & 2013 & 0.1 & 2.5 & not add. & 111.1 & 222.2 & 0.500 & 10.99 \\
\hline
\end{tabular}

According to the literature, the final product of chromium electrocoagulation with Fe electrodes should be chromite $\left(\mathrm{FeCr}_{2} \mathrm{O}_{4}\right.$, ) or a mixture of $\mathrm{FeCr}_{2} \mathrm{O}_{4}, \mathrm{Fe}_{2} \mathrm{O}_{3}, \mathrm{Cr}_{2} \mathrm{O}_{3}$ and/or $\mathrm{Cr}$ and Fe hydroxides. Based on XRD analysis of the solid product, its amorphousness was evident, probably in the form of iron and chromium hydroxides. This amorphousness made it impossible to identify the composition in more detail. Therefore, thermogravimetric analysis was performed for identification of volatile substances and to find thermal conditions for further EC process product treatment to get nonamorphous product with signal at XRD. Thermogravimetric analysis (TGA) combined with XRF analysis before and after TGA measurement was performed to obtain more detailed information on the composition of the product and its behavior at elevated temperatures. The focus was on future heat treatment and subsequent XRD analysis to obtain information on the form of $\mathrm{Cr}$ in the solid product. TGA measurement showed the total change in mass loss which in TG analysis was approximately $34 \mathrm{wt}$ \% (Figure 7). This decrease was recorded in several steps with different intensity and width of the interval. In the first step of weight loss there is a gradual loss of mass up to $400{ }^{\circ} \mathrm{C}$ with a maximum rate of $3 \% / \mathrm{min}$. at $130{ }^{\circ} \mathrm{C}$. In this range, physisorbed water, low molecular weight volatile compounds, solvents and trapped gases could be evolved. The endothermic effect occurred up to approximately $180^{\circ} \mathrm{C}$. This phase corresponds to dehydration, where from about $200{ }^{\circ} \mathrm{C}$ either (a) low-volatile components producing an exothermic effect (C-H-O-N based components) can be released in the oxidizing atmosphere, or (b) the reaction of chlorine as a weak acid with $\mathrm{K}_{2} \mathrm{O}$ and $\mathrm{Na}_{2} \mathrm{O}$ oxides form chlorides or the oxychlorides of the alkali components, the products of which can subsequently be converted into a gaseous state under given temperature conditions. The binding and form of sulfur in the input samples is unclear. Reduced sulfur and chlorine contents after annealing are therefore a prerequisite for the reactions associated with their transition to the gas phase $\left(\mathrm{Cl}_{2}, \mathrm{SO}_{\mathrm{x}}\right)$. In the range of $400-460{ }^{\circ} \mathrm{C}$, a decrease of about $2 \%$ of mass loss was observed with a maximum intensity at $445{ }^{\circ} \mathrm{C}$. If the solid product of EC process was in the form of hydroxides (as was assumed), mass decrease of approx. $24 \%$ in the temperature range of $0-460{ }^{\circ} \mathrm{C}$ may represent water vapor production. Around $600-650{ }^{\circ} \mathrm{C}$ there was $11 \%$ final loss of mass representing the final phase of decomposition, which is probably related to the evaporation of the gas phase of chloride and sulfur components at the end of which is the non-amorphous product in the oxide phase. Above this temperature no weight loss was observed in TG analysis. Based on the results 
of TGA analysis, temperature of $850^{\circ} \mathrm{C}$ was chosen for EC solid product treatment, after which XRD characterization was applied.

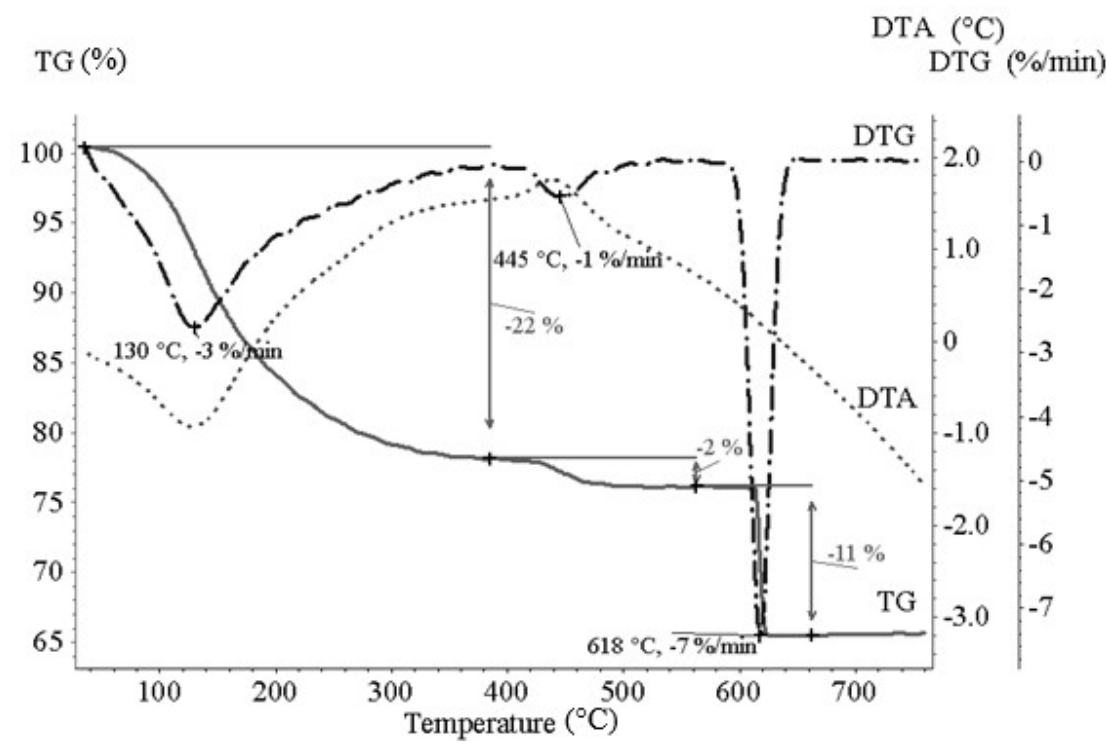

Figure 7. Thermogravimetric analysis (TGA) of EC solid product prepared from leachate of EAFS slag.

Table 3 shows the XRF analysis before and after sample thermal treatment at $850{ }^{\circ} \mathrm{C}$ for $2 \mathrm{~h}$ (energy consumption was $13 \mathrm{kWh}$ ). Changes in the element percentage, mainly Fe and $\mathrm{Cr}$, were observed after samples thermal treatment. The XRF analysis assumes the oxidic character of the samples, which was taken into account in the element analysis in the "balance" item. From the input analysis proportions of iron, chromium, magnesium and sulfur can be confirmed, which however differs in individual samples. In the solid product there are also other elements $\mathrm{P}, \mathrm{Si}, \mathrm{Al}, \mathrm{Co}, \mathrm{K}, \mathrm{Ca}, \mathrm{Ti}, \mathrm{V}$ and $\mathrm{Mn}$ each under $1 \mathrm{wt}$ \% (these elements are also included in the $\Sigma$ elem.)

Table 3. XRF analysis results of EC solid products before and after $\left({ }^{*}\right)$ samples thermal treatment at $850{ }^{\circ} \mathrm{C}$.

\begin{tabular}{cccccccccc}
\hline Sample & Fe & $\mathbf{C r}$ & $\mathbf{C l}$ & $\mathbf{S}$ & $\mathbf{M g}$ & $\Sigma$ Elem. & Balance & Total \% & Ratio Cr/Fe \\
\hline model 1 & 44.88 & 14.93 & 0.351 & 3.53 & 3.85 & 70.87 & 29.00 & 99.87 & 0.3327 \\
model 1 * & 51.72 & 16.96 & 0.070 & 0.464 & 4.65 & 77.43 & 22.48 & 99.90 & 0.3279 \\
EAFS & 42.31 & 15.56 & 2.05 & 1.04 & 2.98 & 72.30 & 32.87 & 99.79 & 0.3678 \\
EAFS * & 46.75 & 17.39 & 0.075 & 0.988 & 4.03 & 73.77 & 27.35 & 99.84 & 0.3720 \\
EAFC & 41.87 & 15.36 & 1.46 & 0.578 & 3.76 & 74.15 & 34.15 & 99.89 & 0.3668 \\
EAFC * & 48.30 & 16.79 & 0.069 & 0.123 & 3.69 & 73.63 & 27.75 & 99.84 & 0.3476 \\
LC FeCr & 43.20 & 15.13 & 1.53 & 0.305 & 4.22 & 74.86 & 32.58 & 99.85 & 0.3502 \\
LC FeCr * & 50.97 & 17.79 & 0.084 & 0.262 & 4.19 & 74.00 & 23.34 & 99.85 & 0.3490 \\
HC FeCr & 34.28 & 15.77 & 0.823 & 0.503 & 3.11 & 73.22 & 42.60 & 99.84 & 0.4600 \\
HC FeCr * & 43.59 & 20.11 & 0.070 & 0.466 & 3.02 & 73.87 & 29.49 & 99.84 & 0.4613 \\
\hline
\end{tabular}

According to results from the TGA analysis, EC solid product samples were treated at $850{ }^{\circ} \mathrm{C}$ for $2 \mathrm{~h}$ to get oxidic form of the product suitable for XRD and SEM-EDX analysis. The aggregates formed during the thermal treatment were homogenized in a mortar. Aliquots of samples EAFS, EAFC, LC FeCr and HC FeCr were taken for SEM-EDX analysis for confirmation of the composition (Figure 8). The amount of $\mathrm{Cr}$ varied from $15.9 \%$ in EAFC to $21.1 \%$ in $\mathrm{HC} \mathrm{FeCr}$. $\mathrm{Cr} / \mathrm{Fe}$ ratio calculated from SEM-EDX analysis was 0.4305 for EAFS, 0.3292 for EAFC, 0.3972 for LC FeCr and 0.4617 for HC FeCr. The SEM-EDX analysis confirmed the composition and amounts of Fe and $\mathrm{Cr}$, which were in good agreement with those from XRF and AAS analysis (compared XRF (Table 3), AAS (Table 2) and SEM-EDX calculated $\mathrm{Cr} / \mathrm{Fe}$ ratio). 

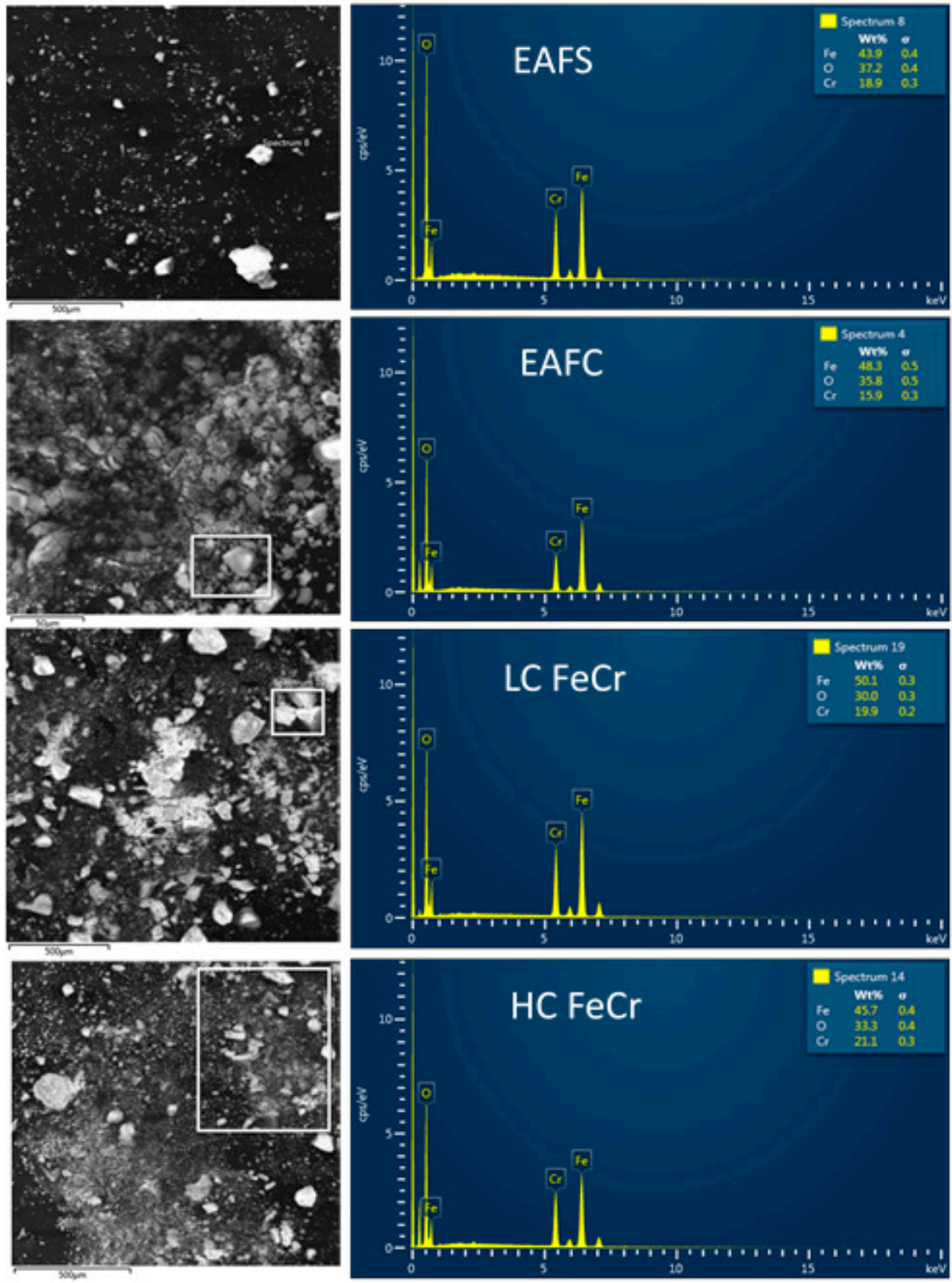

Figure 8. SEM-EDX analysis of EC solid products prepared from leachates EAFS, EAFC, LC $\mathrm{FeCr}$, HCFeCr.

XRD analysis was realized to obtain the information about phase of $\mathrm{Cr}$ and $\mathrm{Fe}$ in the solid product. In Figure 9 is the spectrum for EC solid product prepared from leachate of HC FeCr sample, which was the highest amount of $\mathrm{Cr}$ from all samples. Composition of chromite $\left(\mathrm{FeCr}_{2} \mathrm{O}_{4}\right)$, which was expected as mentioned in the literature, corresponds to rhombohedral crystallographic system (space group no. 167) which is known for $\mathrm{Fe}_{2} \mathrm{O}_{3}$ or $\mathrm{Cr}_{2} \mathrm{O}_{3}$ phases. In the inset plot, the dependence of the lattice parameter a and $c$ taken from the PDF2 database (namely: $\mathrm{Cr}_{2} \mathrm{O}_{3}$ no. 38-1479, $\mathrm{Cr}_{1.3} \mathrm{Fe}_{0.7} \mathrm{O}_{3}$ no.35-1112, $\left(\mathrm{Fe}_{0.6} \mathrm{Cr}_{0.4}\right)_{2} \mathrm{O}_{3}$ no. 34-412 and $\mathrm{Fe}_{2} \mathrm{O}_{3}$ no. 33-664) on the $\mathrm{Cr}$ ration in $(\mathrm{Fe}, \mathrm{Cr})_{2} \mathrm{O}_{3}$ phase is shown. The determined lattice parameters from sample $\mathrm{HC} \mathrm{FeCr}$ were entered into the graph and one could notice that the lattice parameter corresponds to the $\mathrm{Cr}$ fraction approximately 0.3 (the plotted fraction is 0.32 ). 


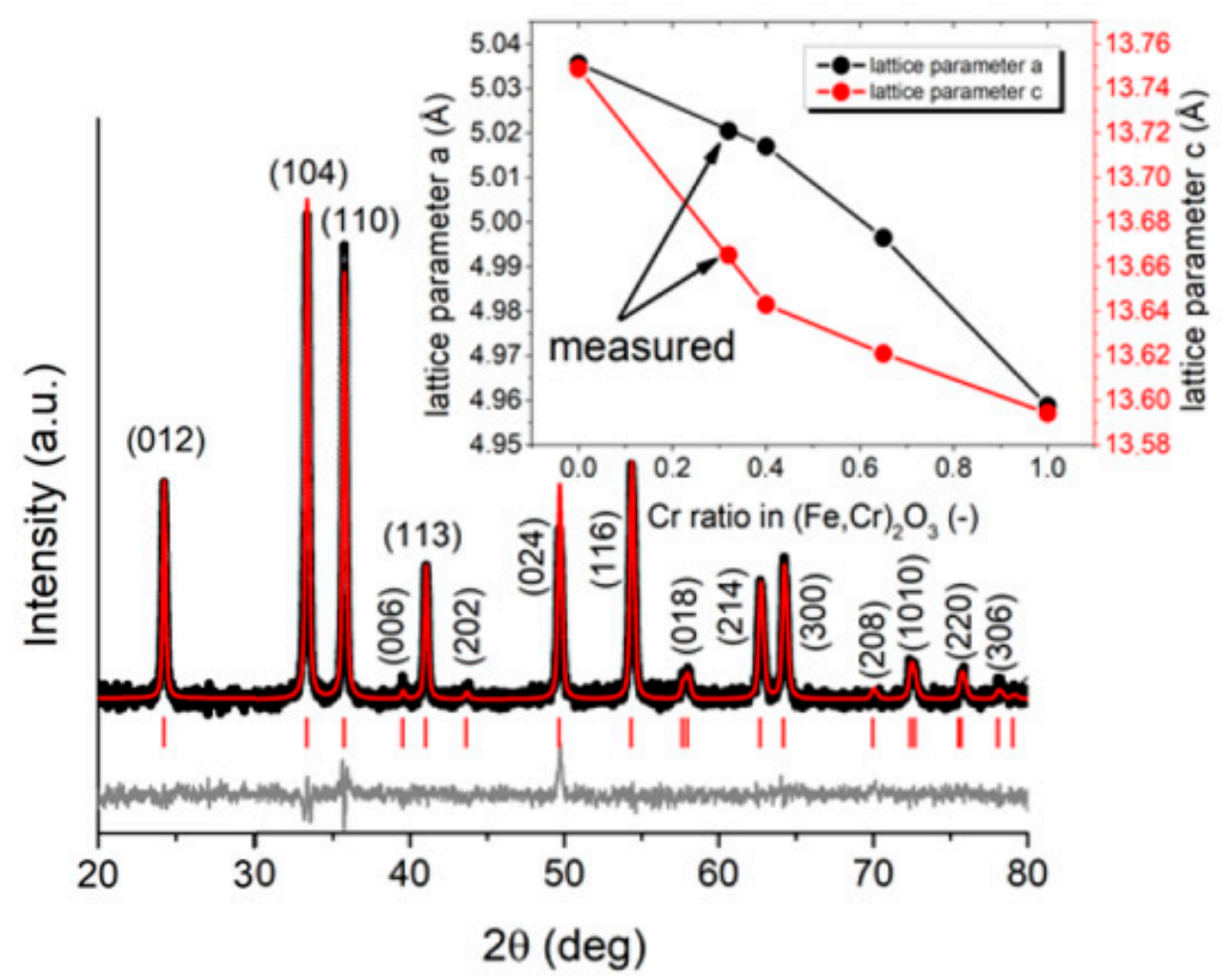

Figure 9. XRD spectrum of EC solid product prepared from leachate of $\mathrm{HC}$ FeCr refined for lattice parameter determination of $(\mathrm{Fe}, \mathrm{Cr})_{2} \mathrm{O}_{3}$ phase. The insert graph shows the place of fitted values between known parameters from PDF2 database.

For confirmation of XRD results, Mössbauer spectroscopy was realized with the aim to characterize the phase composition of the solid product directly after EC process, as well as after its thermal treatment. Room temperature (RT) spectrum of the sample denoted as EAFS (before thermal treatment) is shown in Figure 10. Spectrum recorded at RT exhibits broadened superparamagnetic doublet. The doublet changes to the broadened magnetic six-line pattern at $4.2 \mathrm{~K}$ which is shown in Figure 11. Such a pattern is characteristic for structurally disordered or weakly ordered materials. This spectrum was fitted using distribution of hyperfine magnetic field. Hyperfine parameters are listed in Table 4. Measured data suggest possible presence of iron oxyhydroxide. Similar results were reported by $[32,33]$.

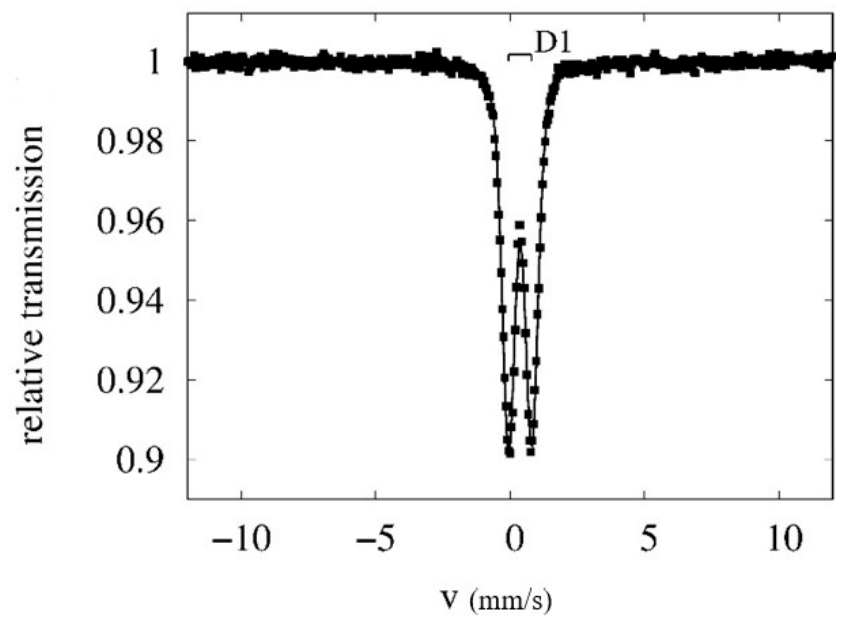

Figure 10. Room temperature (RT) Mössbauer MS spectrum of the EC solid product prepared from leachate of EAFS. 


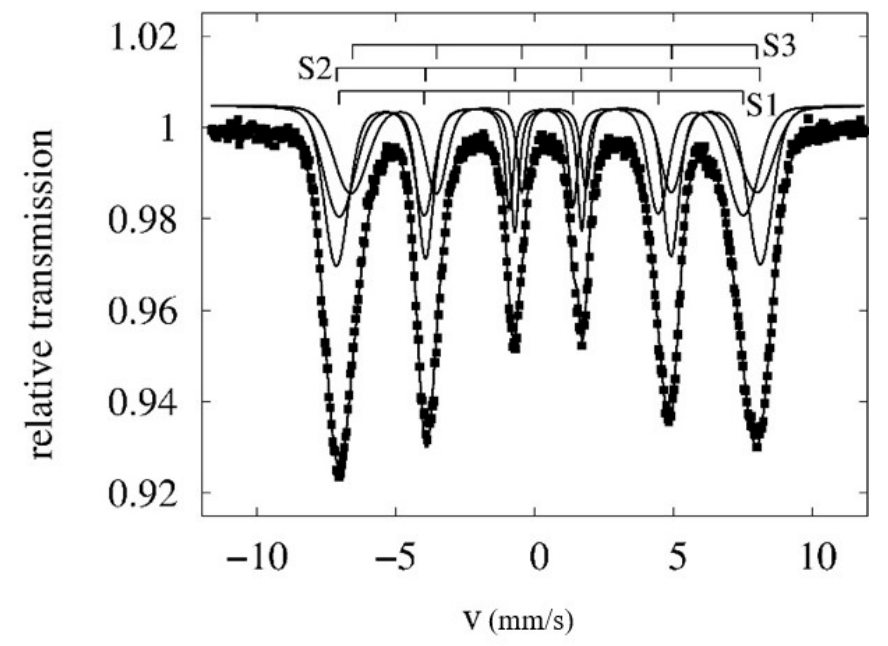

Figure 11. Low temperature Mössbauer spectrum of the EC solid product prepared from leachate of EAFS.

Table 4. Hyperfine parameters of the sample EAFS.

\begin{tabular}{cccc}
\hline Conditions & $<\mathrm{IS}>[\mathrm{mm} / \mathrm{s}]$ & $<\mathrm{QS}>[\mathrm{mm} / \mathrm{s}]$ & $<\mathrm{Bhf}\rangle[\mathrm{T}]$ \\
\hline $\mathrm{RT}$ & $0.37 \pm 0.02$ & $0.87 \pm 0.02$ & - \\
$4.2 \mathrm{~K}$ & $0.47 \pm 0.02$ & $0.00 \pm 0.02$ & $46.2 \pm 0.3$ \\
\hline
\end{tabular}

Annealed sample EAFS* (after thermal treatment) exhibits at RT measurement six-line pattern, which can be seen in Figure 12. Fitting model consists of two sextets denoted as S1 and S2. Hyperfine parameters of these spectral components are listed in Table 5. Sextet S1 exhibits very narrow distribution of hyperfine magnetic field. Values of isomer shift and quadrupole shift are very similar to parameters of hematite. However, the mean value of hyperfine magnetic field is significantly lower. As it was reported earlier by Bhattacharya et al. and Yogi et al., the substitution of iron by chromium in hematite can significantly decrease the value of hyperfine magnetic field [34,35]. Sextet S2 is relatively broad and might be assigned to magnetic relaxation of smaller particles. The low-temperature spectrum corresponding to the sample EAFS* is shown in Figure 13. As it can be seen the model consists of only one sextet. The hyperfine parameters of this component are listed in Table 5. The value of quadrupole shift suggests that the hematite did not undergo Morin transition. This means that the structure remains ferromagnetic, which is possibly caused by the substituent of iron in the structure.

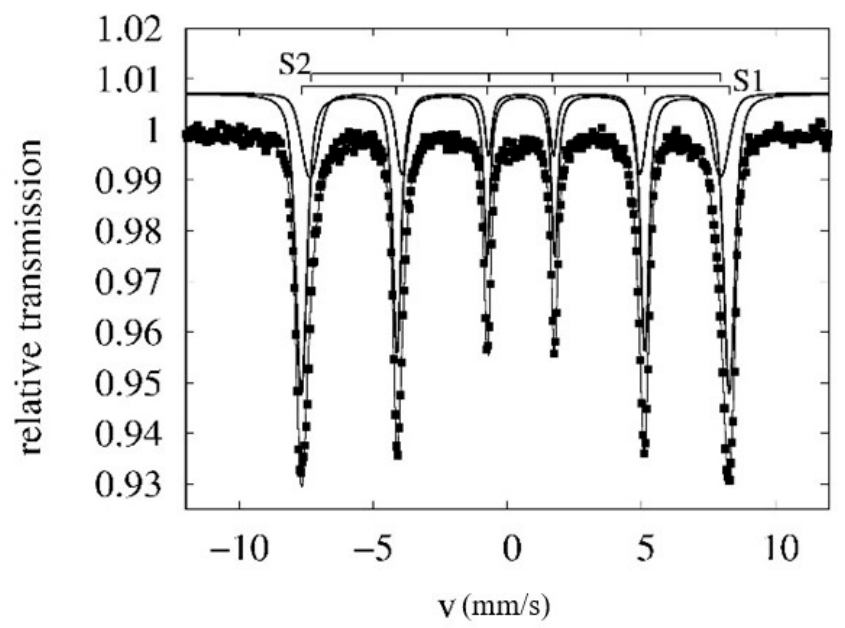

Figure 12. RT Mössbauer spectrum of the EC solid product prepared from leachate of EAFS*. 
Table 5. Hyperfine parameters of the sample EAFS*.

\begin{tabular}{ccccc}
\hline \multicolumn{2}{c}{ Conditions } & $<\mathrm{IS}>[\mathrm{mm} / \mathrm{s}]$ & $<\mathrm{QS}>[\mathrm{mm} / \mathrm{s}]$ & $<\mathrm{Bhf}>[\mathrm{T}]$ \\
\hline \multirow{2}{*}{ RT } & $\mathrm{S} 1$ & $0.40 \pm 0.02$ & $-0.21 \pm 0.02$ & $49.6 \pm 0.3$ \\
$4.2 \mathrm{~K}$ & $\mathrm{~S} 2$ & $0.40 \pm 0.02$ & $-0.21 \pm 0.02$ & $47.6 \pm 0.3$ \\
& $\mathrm{~S} 1$ & $0.48 \pm 0.02$ & $-0.20 \pm 0.02$ & $52.6 \pm 0.3$ \\
\hline
\end{tabular}

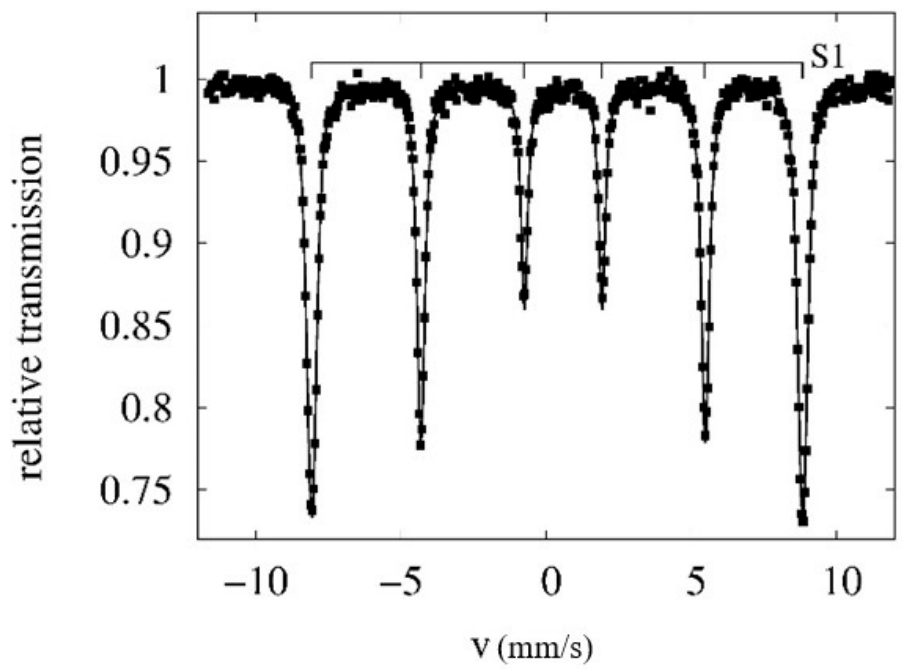

Figure 13. Low temperature Mössbauer spectrum of the EC solid product prepared from leachate of EAFS*.

Results from XRD and Mössbauer spectroscopy are in good agreement and showed us the final product as mixed $\mathrm{Fe}$ and $\mathrm{Cr}$ oxide (EC solid product after thermal treatment). Arroyo et al. [12] described production of $\mathrm{Cr}_{\mathrm{x}} \mathrm{Fe}_{1-\mathrm{x}}(\mathrm{OH})_{3}$ between $\mathrm{pH} 2$ and 6 . The same product was prepared in this work, converted after thermal treatment into the phase $\left(\mathrm{Fe}_{0.6} \mathrm{Cr}_{0.4}\right)_{2} \mathrm{O}_{3}$. There was max. $20 \%$ of $\mathrm{Cr}$ in the produced solid product, and the chromium-to-iron ratio was max. 0.46.

Chromite ore has a spinel structure with a general formula of $(\mathrm{Fe}, \mathrm{Mg}) \mathrm{O} \cdot(\mathrm{Cr}, \mathrm{Al}, \mathrm{Fe})_{2} \mathrm{O}_{3}$. Chromite ore is used for production of ferrochromium alloy. The content of $\mathrm{Cr}_{2} \mathrm{O}_{3}$ for metallurgical-grade chromite ore is in the range $42-55 \%$ (this means a chromium content of $28-37 \%$ ) and the chromium-to-iron ratio is higher than 1.5 [36]. The present paper showed the possibilities of processing secondary waste material (slag) leachates and preparing solid product with parameters approaching chromite ore for further chromium production.

\section{Conclusions}

The evaluated method of electrocoagulation was applied on model and real samples of slag leachates, and proved its relevance for chromium recovery. The broad implication of the presented experimental results provides the basis for the following conclusions:

- Electrocoagulation is an effective tool for removing chromium from the leachates by concentrating in a solid product useful in the production of chromium.

- $\mathrm{pH}$ value of 6 was optimal for EC procedure, due to the reduction of the experiment duration for total precipitation of $\mathrm{Cr}$ and thus minimization the energy consumption. Concentration of $\mathrm{NaCl}$, under the same conditions of $\mathrm{pH}$ and current intensity, had no influence on the experiment duration. This parameter affected only the proportion of Fe in the solid product and the energy consumption during experiments. 
- Application of higher current intensities (1 or 2 A) led to shortening the time of EC process necessary for the total $\mathrm{Cr}$ removal from solution but it led to solution overheating up to $60^{\circ} \mathrm{C}$. $100 \%$ efficiency of chromium removal was achieved for $0.5 \mathrm{~A}$ after $140 \mathrm{~min}$ and for $0.1 \mathrm{~A}$ after 430 min of EC process.

- Thermogravimetric analysis, XRD analysis and Mössbauer spectroscopy of solid products provided description of key product parameters in detail.

- Final EC solid products reached up to $20 \%$ of chromium in the form of substituted hematite. Initial amount of $2-5 \%$ of chromium in slags used for leachates preparation is stated for comparison.

- EC demands application of high current intensities when it is used as waste water treatment technology (solid product composition is insignificant).

- Metals recovery from secondary raw materials could be achieved by employing of low current intensities (metal concentration increases in the final solid product).

Author Contributions: Electrocoagulation experiments, manuscript conception, writing and corrections, L.P. and M.H.; slags leachates preparation and characterization, A.M. and D.A.; TGA experiments and description, R.F.; XRD measurements and description, O.M.; Mössbauer experiments and comments, M.C.; EDX, SEM experiments and description, J.B. All authors have read and agreed to the published version of the manuscript.

Funding: This research was funded by project CHROMIC - efficient mineral processing and Hydrometallurgical Recovery of byproduct Metals from low-grade metal containing secondary raw materials, which received funding from the European Union's Horizon 2020 Research and Innovation program under Grant Agreement $\mathrm{n}^{\circ} 730471$ and European Regional Development Fund Project “Center for Advanced Applied Sciences” No. CZ.02.1.01/0.0/0.0/16 019/0000778.

Acknowledgments: This work was supported by project CHROMIC-efficient mineral processing and Hydrometallurgical Recovery of byproduct Metals from low-grade metal containing secondary raw materials, which received funding from the European Union's Horizon 2020 Research and Innovation program under Grant Agreement $\mathrm{n}^{\circ} 730471$ and European Regional Development Fund Project "Center for Advanced Applied Sciences" No. CZ.02.1.01/0.0/0.0/16 019/0000778.

Conflicts of Interest: The authors declare no conflict of interest.

\section{References}

1. Worldsteel Association. Steel Industry Co-Products. Available online: https://www.worldsteel.org/en/dam/ jcr:1b916a6d-06fd-4e84-b35d-c1d911d18df4/Fact_By-products_2018.pdf (accessed on 20 January 2020).

2. Garcia-Ramos, E.; Romero-Serrano, A.; Zeifert, B.; Flores-Sanchez, P.; Hallen-Lopez, M.; Palacios, E.G. Immobilization of chromium in slags using $\mathrm{MgO}$ and $\mathrm{Al}_{2} \mathrm{O}_{3}$. Steel Res. Int. 2008, 79, 332-339. [CrossRef]

3. Panda, C.R.; Mishra, K.K.; Nayak, B.D.; Rao, D.S.; Nayak, B.B. Release behaviour of chromium from ferrochrome slag. Int. J. Environ. Technol. Manag. 2012, 15, 261-274. [CrossRef]

4. Qing, Z.; Chengjun, L.; Longhu, C.; Xiang, Z.; Maofa, J. Effect of Lime on Stability of Chromium in Stainless Steel Slag. Minerals 2018, 8, 424. [CrossRef]

5. Bayramoglu, M.; Eyvaz, M.; Kobya, M. Treatment of the textile wastewater by electrocoagulation: Economical evaluation. Chem. Eng. J. 2007, 128, 155-161. [CrossRef]

6. Wang, C.T.; Chou, W.L. Performance of COD removal from oxide chemical mechanical polishing wastewater using iron electrocoagulation. J. Environ. Sci. Health Part A 2009, 44, 1289-1297. [CrossRef]

7. Fernandes, A.; Spranger, P.; Fonseca, A.D.; Pacheco, M.J.; Ciríaco, L.; Lopes, A. Effect of electrochemical treatments on the biodegradability of sanitary landfill leachates. Appl. Catal. B Environ. 2014, 144, 514-520. [CrossRef]

8. Kobya, M.; Ciftci, C.; Bayramoglu, M.; Sensoy, M.T. Study on the treatment of waste metal cutting fluids using electrocoagulation. Sep. Purif. Technol. 2008, 60, 285-291. [CrossRef]

9. Zodi, S.; Louvet, J.N.; Michon, C.; Potier, O.; Pons, M.N.; Lapicque, F.; Leclerc, J.P. Electrocoagulation as a tertiary treatment for paper mill wastewater: Removal of non-biodegradable organic pollution and arsenic. Sep. Purif. Technol. 2011, 81, 62-68. [CrossRef]

10. Behloul, M.; Grib, H.; Drouiche, N.; Abdi, N.; Lounici, H.; Mameri, N. Removal of Malathion Pesticide from Polluted Solutions by Electrocoagulation: Modeling of Experimental Results using Response Surface Methodology. Sep. Sci. Technol. 2013, 48, 664-672. [CrossRef] 
11. Inan, H.; Alaydin, E. Phosphate and nitrogen removal by iron produced in electrocoagulation reactor. Desalin. Water Treat. 2014, 52, 1396-1403. [CrossRef]

12. Aroyo, M.G.; Pérez-Herranz, V.; Montanés, M.T.; García-Antón, J.; Guinón, J.L. Effect of pH and chloride concentration on the removal of hexavalent chromium in a batch electrocoagulation reactor. J. Hazard. Mater. 2009, 169, 1127-1133. [CrossRef] [PubMed]

13. Keshmirizadeh, E.; Yousefi, S.; Rofouei, M.K. An investigation on the new operational parameter effective in $\mathrm{Cr}(\mathrm{VI})$ removal efficiency: A study on electrocoagulation by alternating pulse current. J. Hazard. Mater. 2011, 190, 119-124. [CrossRef] [PubMed]

14. Xu, H.Y.; Yang, Z.H.; Luo, Y.L.; Zeng, G.M.; Huang, J.; Wanga, L.; Song, P.P.; Yang, X. A novel approach to sustain Fe0-electrocoagulation for $\mathrm{Cr}(\mathrm{VI})$ removal by optimizing chloride ion. Sep. Purif. Technol. 2015, 156, 200-206. [CrossRef]

15. Janin, A.; Zaviska, F.; Drogui, P.; Blais, J.F.; Mercier, G. Selective recovery of metals in leachate from chromated copper arsenate treated wastes using electrochemical technology and chemical precipitation. Hydrometallurgy 2009, 96, 318-326. [CrossRef]

16. Golder, A.K.; Samanta, A.N.; Ray, S. Removal of Cr3+ by electrocoagulation with multiple electrodes: Bipolar and monopolar configurations. J. Hazard. Mater. 2007, 141, 653-661. [CrossRef]

17. Khan, S.U.; Islam, D.T.; Farooqi, I.H.; Ayub, S.; Basheer, S. Hexavalent chromium removal in an electrocoagulation column reactor: Process optimization using CCD, adsorption kinetics and $\mathrm{pH}$ modulated sludge formation. Process Saf. Environ. Prot. 2019, 122, 118-130. [CrossRef]

18. Cherifi, M.; Hazourli, S.; Pontvianne, S.; Lapicque, F.; Leclerc, J.P. Electrokinetic removal of aluminum and chromium from industrial wastewater electrocoagulation treatment sludge. Desalin. Water Treat. 2015, 57, 1-16. [CrossRef]

19. Heidmann, I.; Calmano, W. Removal of $\mathrm{Zn}(\mathrm{II}), \mathrm{Cu}(\mathrm{II}), \mathrm{Ni}(\mathrm{II}), \mathrm{Ag}(\mathrm{I})$ and $\mathrm{Cr}(\mathrm{VI})$ presentin aqueous solutions by aluminium electrocoagulation. J. Hazard. Mater. 2008, 152, 934-941. [CrossRef]

20. Zewail, T.M.; Yousef, N.S. Chromium ions (Cr6+\& Cr3+) removal from synthetic wastewaterby electrocoagulation using vertical expanded Fe anode. J. Electroanal. Chem. 2014, 735, 123-128. [CrossRef]

21. Mouedhen, G.; Feki, M.; De Petris-Wery, M.; Ayedi, H.F. Electrochemical removal of Cr(VI)from aqueous media using iron and aluminum as electrode materials: Towards a better understanding of the involved phenomena. J. Hazard. Mater. 2009, 168, 983-991. [CrossRef]

22. Kakakhel, L.; Lutfullah, G.; Bhanger, M.I.; Shah, A.; Niaz, A. Electrolytic recovery of chromium salts from tannery wastewater. J. Hazard. Mater. 2007, 148, 560-565. [CrossRef]

23. Benhadji, A.; Ahmed, M.T.; Maachi, R. Electrocoagulation and effect of cathode materials on the removal of pollutants from tannery wastewater of Rouiba. Desalination 2011, 277, 128-134. [CrossRef]

24. Lakshmipathiraj, P.; Raju, G.B.; Basariya, M.R.; Parvathy, S.; Prabhakar, S. Removal of Cr(VI) by electrochemical reduction. Sep. Purif. Technol. 2008, 60, 96-102. [CrossRef]

25. Jin, W.; Du, H.; Zheng, S.; Zhang, Y. Electrochemical processes for the environmental remediation of toxic Cr(VI): A review. Electrochim. Acta 2016, 191, 1044-1055. [CrossRef]

26. Kim, J.D.; Pyun, S.I. The effects of applied potential and chloride ion on the repassivation kinetics of pure iron. Corros. Sci. 1996, 38, 1093-1102. [CrossRef]

27. Vasudevan, S.; Lakshmi, J.; Sozhan, G. Studies on the Al-Zn-In-alloy as anode material for the removal of chromium from drinking water in electrocoagulation process. Desalination 2011, 275, 260-268. [CrossRef]

28. Barrera-Diaz, C.; Lugo-Lugo, V.; Roa-Morales, G.; Natividad, R.; Martinez-Delgadillo, S.A. Enhancing the electrochemical $\mathrm{Cr}(\mathrm{VI})$ reduction in aqueous solution. J. Hazard. Mater. 2011, 185, 1362-1368. [CrossRef]

29. Horckmans, L.; Möckel, R.; Nielsen, P.; Kukurugya, F.; Vanhoof, C.; Morillon, A.; Algermissen, D. Multi-Analytical Characterization of Slags to Determine the Chromium Concentration for a Possible Re-Extraction. Minerals 2019, 9, 646. [CrossRef]

30. Lutterotti, L. Total pattern fitting for the combined size-strain-stress-texture determination in thin film diffraction. Nucl. Instrum. Methods Phys. Res. Sect. B 2010, 268, 334-340. [CrossRef]

31. Žák, T.; Jirásková, Y. CONFIT: Mössbauer spectra fitting program. Surf. Interface Anal. 2006, 38, 710-714. [CrossRef]

32. Parga, J.R.; Cocke, D.L.; Valverde, V.; Gomes, J.A.G.; Kesmez, M.; Moreno, H.; Weir, M.; Mencer, D. Characterization of Electrocoagulation for Removal of Chromium and Arsenic. Chem. Eng. Technol. 2005, 28, 605-612. [CrossRef]

33. Parga, J.R.; Vazquez, V.; Gonzalez, G.; Cisneros, M.M. Thermodynamic Studies of Chromium Adsorption on Iron Species Generated by Electrocoagulation. Chem. Eng. Technol. 2010, 33, 1582-1590. [CrossRef] 
34. Bhattacharya, A.K.; Hartridge, A.; Mallick, K.K.; Majumdar, C.K.; Das, D.; Chintalapudi, S.N. An X-ray diffraction and Mössbauer study of nanocrystalline Fe2O3-Cr2O3 solid solutions. J. Mater. Sci. 1997, 32, 557-560. [CrossRef]

35. Yogi, A.; Varshney, D. Magnetic and structural properties of pure and Cr-doped haematite: $\alpha-\mathrm{Fe}_{2}-\mathrm{xCrxO}_{3}$ $(0 \leq \mathrm{x} \leq 1)$. J. Adv. Ceram. 2013, 2, 360-369. [CrossRef]

36. Buschow, K.H.J.; Cahn, R.W.; Flemings, M.C.; Ilschner, B.; Kramer, E.J.; Mahajan, S.; Veyssière, P. Production of Chromium Ferroalloys. In Encyclopedia of Materials: Science and Technology; Elsevier Ltd.: Oxford, UK; Pergamon: Oxford, UK, 2001; ISBN 978-0-08-043152-9.

Publisher's Note: MDPI stays neutral with regard to jurisdictional claims in published maps and institutional affiliations.

(C) 2020 by the authors. Licensee MDPI, Basel, Switzerland. This article is an open access article distributed under the terms and conditions of the Creative Commons Attribution (CC BY) license (http://creativecommons.org/licenses/by/4.0/). 